Raf. J. Sci.,Vol.27, No.4 /Special Issue for the Third Scientific Conference of Biology, pp.33-39, 2018

\title{
Isolation and Identification of Microorganisms from Patients with Halitosis
}

\author{
Rafit J. Al-Adole \\ Ghada Y. Abdul-Rahman \\ College of Dentistry/ University of Mosul
}

(Received 20/5/2018 ; Accepted 1/11/2018)

\begin{abstract}
Twenty-eight patients suffering from oral halitosis were subjected to this study (14 males and 14 females), their ages range between 18 to 65 years were diagnosed clinically. Ninety-five samples were collected by sterile paper points (size 50) or sterile cotton swab and transported in thioglycolate broth and cultured on blood agar in aerobic or anaerobic conditions for (48-72 hours), the identification of the bacteria was carried out using morphological and cultural characteristics, biochemical tests and antibiotics susceptibility tests. The results showed that 13 different bacterial species isolated in this study ((Bacteriodes spp. (14 isolate), Viridans Streptococci (10 isolates), Peptostreptococci spp. (9 isolates), Actinomyces spp. (6 isolates), Porphyromonas spp. (4 isolates), Fusobacterium spp. (4 isolates), Veillonella spp. (4 isolates), Non.coagulase Staphylococcus (3 isolates) Prevotella spp (one isolate), Propinobacterium spp. (one isolate) Tetragenococci spp. (one isolate), Eubacterium spp. (one isolate), and Staphylococcus aureus (one isolate). The conclusion is the dominance of different genera and species of anaerobic bactria in cases of halitosis.
\end{abstract}

Keywords: halitosis, malodor, Bacteroides, Peptostreptococci, Actinomyces, Porphyromonos, Fusobacterium, Veillonella, Prevotella, Propinobacterium, Eubacterium, Staphylococcus aureus.

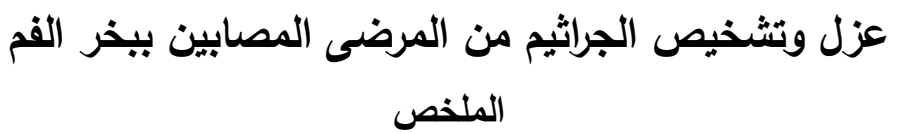

تم تتخيص ثمانية وعشرون شخصا من الذين يعانون من بخر الفم بالفحص السريري (14 ذكر و14 أنتى) وتتراوح أعمارهم بين (18-65) سنة. و جمعت نسع وخمسون عينة باستعمال الرؤوس الورقية المعقمة (حجم 50) أو مسحات قطنية معقمة ثم نقلها في مرف thioglycolate وزرعت على وسط اكار الدم في ظروف هوائية أو لاهوائية لمدة (48-72) ساعة ونت

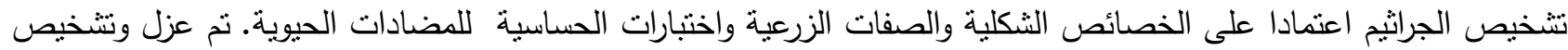
ثلاثة عشر نوعا من الجراثيم ( أربعة عشر عزلة من جنس Bacteriodes، عشر عزلات من جنس Peptostreptococus تسع عزلات من جنس مزلات من جنس Actinomycestreptococi جنس Porphymonos اربع عزلات من جنس Fusobacterium، اربع عزلات من جنس Veillonella، ثلاث عزلات من جنس Non-coagulase Staphylococcus. وعزلة من جن Prevotella)، وعزلة من جنس Propinobacterium، وعزلة من جنس Tetragenococci، وعزلة من جنس Eubacterium ، وعزلة من جنس Staphylococcus aureus.

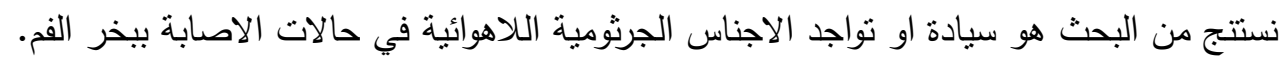




\section{INTRODUCTION}

Halitosis, is a general term used to describe unpleasant breath emitted from a patients mouth regardless of whether the odorous substances in the breath originate from oral or non-oral sources. Although oral malodor is common and most people have some element of transient unpleasant oral odor at some time there are no universally accepted standard criteria, objective or subjective, that define a halitosis patient. According to the American Dental Association, 50\% of the adult population have suffered from an occasional oral malodor disorder, while $25 \%$ appear to have a chronic problem ((Porter and Scully, 2006; Cortelli et al., 2008; Settineri et al., 2010).

The most popularly accepted theory on bad breath is that volatile sulphur compounds (VSCs), hydrogen sulfide and methyl mercaptan are the main components of oral malodor originating from the mouth. Hydrogen sulfide is produced from the dorsum of the tongue, while methyl mercaptan and dimethyl disulfide are produced in periodontal disease sites.

Cysteine and methionine are the sulfur-containing amino acids that serve as substrates for VSC-producing bacteria and are catabolized to volatile gasses, mainly hydrogen sulfide and methyl mercaptan (Young et al., 2001 ; Oeding, 2005).

The source of oral malodor is located in the oral cavity in up to $90 \%$ of people and only a small percentage of cases may be due to non-oral causes.

Salivary hypofunction deminishes the self-cleansing action of the oral cavity, and lower levels overnight frequently result in "morning breath". When saliva evaporates, non sulfur-containing gases (eg, cadaverine, putrescine, butyric, indole) can be released in addition to the VSCs, contributing to halitosis in the patient with salivary hypofunction.

Sources of necrosis or hemorrhage in the oral cavity (dentoalveolar infections, periodontal diseases, oral cancers) produce foul odors. Although dental caries does not produce bad breath, it creates food traps as do overhanging, subgingival, and open restorations. Similarly, poor maintenance and overnight use of dental prostheses can produce malodors as a result of poor hygiene or decreased nighttime salivary flow. Although most types of gingivitis and periodontitis can give rise to malodor, acute necrotizing ulcerative gingivitis (Vincent's disease, trench mouth) causes the most notable halitosis (Silverman et al., 2001; Porter and C Scully, 2006 ; Cortelli et al., 2008; Crispan Scully, 2010).

Several systemic diseases also produce halitosis. Respiratory infections involving gramnegative anaerobic bacteria, tuberculosis, pneumonia, and obstructions (foreign bodies), tumors (lung cancer), and the production of pus (empyema, bronchiectasis) can all contribute to the emission of foul odors from the nasal cavity. In diabetic keto-acidosis, (and some diet e.g. alcohol, high fat, garlic), the circulatory system carries their metabolites through the lungs, and they are expired, resulting in halitosis, individuals with gastrointestinal diseases suffer from halitosis. Hepatic and renal failure, leukemias and other blood dyscrasias, and trimethylaminuria produce malodors as well (Oeding, 2005).

There are several physiological factors which predisposes toward bad breath:-stress, menstruation, certain foods (for example, garlic, onion, alcohol) trimethylaminuria (fish odor syndrome), Ovulation in women has been associated with halitosis and is due to the oral tissues that are renewed frequently caused by a rise in estrogen (Eli et al., 2001).

Medications and chemotherapy can directly affect the oral cavity, resulting in halitosis. The most common medications associated with halitosis are those that inhibit salivary output include analgesics, anticholinergics, antidepressants, antihypertensives, sychotherapeutic, and others. Other medications can produce an odor in the body and can also distort the taste and smell. These include antimicrobial agents, antirheumatic, antihypertensive, and psychopharmaco logical drugs (Field and Longman, 2005).

The two primary methods used for the clinical analysis of oral malodor are organoleptic measurement and instrumental analysis (Tanaka et al., 2004), other methods like salivary incubation test, ammonia concentration, Ninhydrin method and Broad-range PCR method also 
important because non cultivable bacterial species are more numerous than cultivable bacterial species.

Anaerobic bacteria are responsible for the foul odor, although there is a general consensus that Gram-negative oral micro-organisms are responsible for most cases of oral malodor, the actual species responsible for malodor production are not known. Thus, it appears that it is the metabolic activity of the mixed microbiota rather than the bacterial load, or genus types present, that most contributes to oral malodor (Hartley et al.,1996 ; Goldberg et al., 1997; Wray et al., 2003).

\section{MATERIALS AND METHODS}

The study was performed on 28 adult patients (14 male and14 female), their ages between 18 to 65 years, who attended the Dental educational hospital, oral diagnosis sector, college of dentistry at Mosul University. All the patients suffered from halitosis.

Patients who received antibiotic during last two weeks, ate any meal that generates strong odors on the previous day or in the morning of the test, smoked within an hour before test, chewed gum, wore scented personal-care products, brushed or rinsed with strong odorous compounds, were excluded. Dental examination was performed on the dental chair at oral diagnosis sector under artificial light. Different clinical variables were used and collected by same examiner.

When careful clinical examination was ended, the examiner had to prospect the origin of halitosis; deep pockets, heavy calculus, large destructive carious tooth, and retained root. After isolation with cotton rolls, single sterile point size 50 (Vevey Suisse, Swizerland) was inserted for 30 seconds in the prospected site by using sterile tweezzers and placed immediately in sterile screw-capped vials containing (4) $\mathrm{ml}$ of thioglycolate broth as reducing transport medium for anaerobic bacteria. The tongue had to be scraped several times with sterile tongue scraper (Trisa, Swizerland). This scraping produces thick brown fluids. Another sterile point size 50 was inserted for 30 seconds in this brown fluids and by using sterile tweezzers, and was placed immediately in another sterile screw-capped vials containing (4) $\mathrm{ml}$ of thioglycolate broth. This means that we had two vials for each patient but in case of good oral hygiene (healthy gingivae and sound teeth), only one vial containing sample from tongue scrapings. In a sterile hood, each screw-capped vial of thioglycolate broth was inoculated using sterile cotton swap then this swab was spread on two freshly prepared blood agar plates using streaking method (one for aerobic and another for anaerobic). Blood agar plates were incubated anaerobically using anaerobic jar with gas generating system for 48-72 hours at $37 \mathrm{C}$. The other blood agar plates incubated directly in the same incubator for 48-72 hours at $37 \mathrm{C}$ (Summanen, 1999). Colonies of different characteristics were isolated and idenified using various methods.Identification in this study was carried out according to Bergey $\mathrm{s}$ manual of determinative bacteriology..(Holdman et al., 1984; Forbes et al., 2007; Al-Rassam and Shareef, 2006; Al-Ubaidy and Shareef, 2008). Gram stain is an important rapid tool for diagnosis.Detection of fluorescence under long wave UV light $(360 \mathrm{~nm})$ is a useful tool for rapid presumptive identification of some anaerobic bacteria. Detection of Capsule, Cytochome oxidase Test, Catalase Test, Optochin Test, Growth on Mitis Salivaris Agar(MSA). Antibiotics Sensitivity Tests by Kirby-Bauer method modified and recommended by Wolrd Health Organization (WHO) was used, and the sensitivity against Vancomycin, Kanamycin, Colistin, Optochin, Metronidazole and Penicillin was carried out.

\section{RESULTS}

The samples in this study consisted of twenty-eight subjects who suffered from oral halitosis. They attended the College of Dentistry at Mosul University asking for diagnosis and treatment.

The sample consisted of 14 males and 14 females, their ages ranged between 18 to 65 years. 
Table 1: Age and gender distribution

\begin{tabular}{|l|c|c|c|c|c|c|}
\hline Gender & N & Age Mean(years) & Minimum age & $\begin{array}{c}\text { Maximum } \\
\text { Age }\end{array}$ & $\begin{array}{c}\text { Std. } \\
\text { Deviation }\end{array}$ & $\begin{array}{c}\text { Std. error of } \\
\text { mean }\end{array}$ \\
\hline Male & 14 & 31.0714 & 19.00 & 56.00 & 12.74281 & 3.40566 \\
\hline Female & 14 & 37.2143 & 18.00 & 65.00 & 15.42814 & 4.12334 \\
\hline Total & 28 & 34.1429 & 18.00 & 65.00 & 14.23276 & 2.68974 \\
\hline
\end{tabular}

Fifty nine bacterial samples (within 14 different bacterial species) from 28 patients suffered from halitosis were isolated (Table 2).

Table 2: Microscopical and Macroscopical Characteristics of the Isolated Bacteria

\begin{tabular}{|c|c|c|c|c|}
\hline & Organism & $\begin{array}{l}\text { No. of } \\
\text { isolates }\end{array}$ & Gram stain & Colonial appearance \\
\hline 1 & Bacteriodes species & 13 & Gram negative pleomorphic rods & $\begin{array}{l}\text { Gray-white, circular,convex,non- } \\
\text { hemolytic }\end{array}$ \\
\hline 2 & Viridans Streptococci & 10 & $\begin{array}{l}\text { Gram positive cocci arranged in } \\
\text { chains or pairs andcan grow in M- } \\
\text { S-A }\end{array}$ & $\begin{array}{l}\text { On M-S-A appear small blue } \\
\text { colonies but on blood agar were } \\
\text { non-hemolytic }\end{array}$ \\
\hline 3 & Peptostreptococci species & 9 & $\begin{array}{l}\text { Gram positive large } \\
\text { arranged in chains }\end{array}$ & $\begin{array}{l}\text { Gray-white, opaque colonies with } \\
\text { fetid odor }\end{array}$ \\
\hline 4 & Actinomyces species & 6 & $\begin{array}{l}\text { Gram-positive coccobacilli and } \\
\text { beaded filamentous rods }\end{array}$ & Small, convex gray -white colony \\
\hline 5 & Porphyromonas species & 4 & Gram - positive coccobacilli & $\begin{array}{l}\text { Dark brown to black and compared } \\
\text { to Prevotella were more mucoid }\end{array}$ \\
\hline 6 & Fusobacterium speices & 4 & $\begin{array}{l}\text { Gram- negative,pale-staining,long } \\
\text { spindle with pointed ends }\end{array}$ & $\begin{array}{l}\text { Gray-white colonies fluoresces } \\
\text { under UV light (hemolytic or non) }\end{array}$ \\
\hline 7 & Veillonella species & 4 & Gram-negative small cocci & $\begin{array}{l}\text { Small, transparent,grayish-white } \\
\text { smooth colonies fluoresces under } \\
\text { UV light }\end{array}$ \\
\hline 8 & $\begin{array}{l}\text { Coagulase-negative } \\
\text { Staphylococcus }\end{array}$ & 3 & $\begin{array}{l}\text { Strongly Gram-positive cocci } \\
\text { arranged in irregular clusters }\end{array}$ & $\begin{array}{l}\text { Round, smooth, raised, and } \\
\text { glisting grey to deep golden yellow } \\
\text { colonies }\end{array}$ \\
\hline 9 & Prevotella species & 1 & $\begin{array}{l}\text { Gram-negative short rods or } \\
\text { coccobacilli }\end{array}$ & $\begin{array}{l}\text { Small, dark black, smooth, shiny } \\
\text { colonies fluoresce brick red under } \\
\text { UV light }\end{array}$ \\
\hline 10 & Propinobacterium Species & 1 & $\begin{array}{l}\text { Pleomorphic, anaerobic Gram- } \\
\text { positive rods }\end{array}$ & $\begin{array}{l}\text { Circular, entire, convex, glisting } \\
\text { and opaque colonies }\end{array}$ \\
\hline 11 & Tetragenococci Species & 1 & Gram - positive spherical tetrads & $\begin{array}{l}\text { Smooth, entire, white, convex } \\
\text { colonies }\end{array}$ \\
\hline 12 & Eubacterium species & 1 & $\begin{array}{l}\text { Uniform or pleomorphic,Gram- } \\
\text { positive rods }\end{array}$ & $\begin{array}{l}\text { Circular,entire,low } \\
\text { convex, white,smooth colonies }\end{array}$ \\
\hline 13 & Staphylococcus aureus & 1 & $\begin{array}{l}\text { Strongly Gram-positive cocci } \\
\text { arranged in irregular clusters }\end{array}$ & $\begin{array}{l}\text { Grey to white colonies on primary } \\
\text { isolation }\end{array}$ \\
\hline & Total & 58 & & \\
\hline
\end{tabular}


Table 3: Antibiotic sensitivity tests for identification of isolated bacteria

\begin{tabular}{|c|c|c|c|c|c|c|c|}
\hline & Organism & $\begin{array}{l}\text { Vancomycin } \\
30 \mu \mathrm{g}\end{array}$ & $\begin{array}{l}\text { Kanamycin } \\
30 \mu \mathrm{g}\end{array}$ & $\begin{array}{l}\text { Colistin } \\
10 \mu \mathrm{g}\end{array}$ & $\begin{array}{l}\text { Optochin } \\
30 \mu \mathrm{g}\end{array}$ & $\begin{array}{l}\text { Metronidazole } \\
5 \mu \mathrm{g}\end{array}$ & $\begin{array}{l}\text { Penicillin } \\
10 \mu \mathrm{g}\end{array}$ \\
\hline 1 & Bacteriodes species & $\mathrm{R}$ & $\mathrm{R}$ & $\mathrm{R}$ & $\ldots \ldots$ & $\mathrm{S}$ & $\mathrm{R}$ \\
\hline 2 & $\begin{array}{l}\text { Viridans } \\
\text { Streptococci }\end{array}$ & $\cdots \cdots$ & $\ldots$ & $\cdots \cdots$ & $\mathrm{R}$ & .... & $\mathrm{S}$ \\
\hline 3 & $\begin{array}{l}\text { Peptostreptococci } \\
\text { species }\end{array}$ & S & $\mathrm{S}$ & $\mathrm{R}$ & $\cdots \cdots$ & $\cdots \cdots$ & $\cdots \cdots$ \\
\hline 4 & $\begin{array}{l}\text { Actinomyces } \\
\text { species }\end{array}$ & $\cdots \cdots$ & .... & $\ldots \ldots$ & $\ldots$. & $\mathrm{R}$ & $\ldots$. \\
\hline 5 & $\begin{array}{l}\text { Porphyromonos } \\
\text { species }\end{array}$ & S & $\mathrm{R}$ & $\mathrm{R}$ & $\ldots \ldots$ & $\mathrm{S}$ & $\ldots \ldots$ \\
\hline 6 & $\begin{array}{l}\text { Fusobacterium } \\
\text { speices }\end{array}$ & $\mathrm{R}$ & S & $\mathrm{S}$ & $\ldots \ldots$ & $\mathrm{S}$ & $\ldots \ldots$ \\
\hline 7 & $\begin{array}{l}\text { Veillonella } \\
\text { species }\end{array}$ & $R$ & $S$ & $S$ & .... & .... & $\ldots$ \\
\hline 8 & $\begin{array}{l}\text { Coagulase- } \\
\text { negative } \\
\text { Staphylococcus }\end{array}$ & .... & $\ldots \ldots$ & $\cdots$. & $\ldots \ldots$ & .... & $\cdots \cdots$ \\
\hline 9 & Prevotella species & $R$ & $R$ & $S$ & $\ldots$. & $S$ & $\ldots$. \\
\hline 10 & $\begin{array}{l}\text { Propinobacterium } \\
\text { Species }\end{array}$ & $\cdots \cdots$ & $\cdots$ & $\cdots$ & $\cdots$ & $\cdots$ & $\cdots$ \\
\hline 11 & $\begin{array}{l}\text { Tetragenococci } \\
\text { Species }\end{array}$ & $S$ & .... & $\ldots \ldots$ & $\ldots \ldots$ & .... & $\cdots$ \\
\hline 12 & $\begin{array}{l}\text { Eubacterium } \\
\text { species }\end{array}$ & $\ldots$. & $\ldots$ & $\ldots$. & $\ldots$ & .... & $\ldots$. \\
\hline 13 & $\begin{array}{l}\text { Staphylococcus } \\
\text { aureus }\end{array}$ & .... & ..... & $\ldots$. & $\ldots$. & $\ldots$. & $\ldots .$. \\
\hline
\end{tabular}

$\mathrm{S}=$ microorganism was sensitive to the antibiotic, $\mathrm{R}=$ microorganism was resistant to the antibiotic $\ldots .=$ the antibiotic test was not necessary

\section{DISCUSSION}

Bad breath can be a crippling social problem, and standard dental treatments and mouthwashes often recommended provide only temporary relief. Halitosis differs from the temporary mouth odors caused by certain foods or drinks: persistent malodor is primarily the result of microbial metabolism.

The mouth is a home to hundreds of bacterial species that, as a result of protein digestion, produce several fetid substances. The role of volatile sulfur compound (VSC)-producing bacteria colonizing the oral tissues has been implicated as a main cause for halitosis (Yosef et al., 2006). Oral malodor has a complex etiology with extrinsic and intrinsic pathways. Extrinsic causes include tobacco, alcohol and certain foods such as onions, garlic and certain spices. Substances absorbed into the circulatory system may be released in pulmonary air or saliva as volatile odoriferous compounds derived from foods. Extrinsic causes of oral malodor are best controlled by eliminating the intake of offensive substances. Intrinsic causes of bad breath are oral and systemic in origin. In general, roughly 10 percent of these cases are of systemic origin; approximately 90 percent of the cases are of intraoral origin (Dowell and Kassebaum, 1993). 
Although the microbiology of the human oral cavity has been investigated thoroughly, the oral microflora remains incompletely characterized. Most studies focused on cultivable microorganisms, which constituted only 1 to 10 percent of all microbial species (Al-Rassam and Shareef, 2006; AlUbaidy and Sharif, 2008). Consequently, these studies have been biased toward "what grows" and have ignored "what does not grow" (Kazor et al., 2003).

From 28 patients suffering from oral halitosis, only14 bacterial species were isolated and identified. These cultivable species included gram-positive and gram-negative, aerobic and anaerobic, frequent and rare bacteria. The non- cultivable species need more complex methods to isolate as BANA assay and PCR method. However, no obvious association exists between oral malodor and any specific bacterial infection, suggesting that halitosis reflects complex interactions between several oral bacterial species. These bacterial interactions are most likely to occur in the gingival crevices and periodontal pockets, but oral malodor can also arise from the posterior dorsal tongue (and this explains why oral malodor may sometimes occur in people with good oral hygiene) (Porter and Scully, 2006).

It had been shown that a variety of gram negative and a few gram positive bacteria that are usually retained in periodontal pockets or on the dorsum of the tongue, produce $\mathrm{H} 2 \mathrm{~S}$ and $\mathrm{CH}_{3} \mathrm{SH}$, In 99\% of cases those responsible for this symptom in the oral cavity are gram-negative anaerobic bacteria which generate sulfur compounds (methyl mercaptan and hydrogen sulphate) and some volatile fatty acids which also have an unpleasant smell. (Young et al., 2001; Salvador, 2001).

The oral microbes most likely to cause the oral malodour are gram negative bacteria and include Prevotella melaninogenica, Treponema denticola, Porphyromonas gingivalis, $P$. endodontalis, Prevotella intermedia, Bacteroides loescheii, Enterobacteriaceae, Tannerella forsythensis (Bacteroides forsythus), Centipeda periodontii, Eikenella corrodens, Fusobacterium nucleatum vincentii, F. nucleatum nucleatum, F. nucleatum polymorphum, F. eriodonticum, Veillonella species, Actinomyces species and Streptococcus species (Porter and Scully, 2006) (Cortelli et al., 2008).

The tongue is a major site of oral malodor production while periodontal disease and other factors seem to be only a fraction of the overall problem. The papillary structure of the dorsum represents a unique ecological niche in the oral cavity, offering a large surface area that favors the accumulation of oral debris and microorganisms. Although the bacteria of the tongue have been implicated as a major source of odor production in subjects with halitosis, the bacterial composition of the tongue is still not well characterized and due to its complexity, the characteristics of tongue biofilm microflora and its relationship with oral malodour remain unclear (Cortelli et al., 2008).

We suggest identification of microorganisms responsible for oral halitosis by using Polymerization Chain Reactions (PCR) since the majority of these microorganisms are noncultivable.

\section{REFERENCES}

Al-Rassam, Z.T.; Shareef, A.Y. (2006). Urinary tract infections caused by Alcaligenes spp. in diabetic patients. Raf. J. Sci., 17(9),137-146.

Al-Ubaidy, S.I.; Sharif, A.Y. (2008). Microbial contamination of white soft cheese in Ninavah governorate. Raf. J. Sci., 19(2), 115-129.

Cortelli, J.R.; Barbosa, M.; Westphal, M.A. (2008). Halitosis: a review of associated factors and therapeutic approach. Braz. Oral Res., 22(1),1344-1356.

Crispian, S. (2008). Halitosis. BMJ Clini. Evidence., 7, 1305-1309.

Dowel, M.C.; Kassbaum, J.R. (1993). Diagnosing and treating halitosis. J. Am. Dent. Assoc.,124, 55-64.

Eli, L.; Baht, R.; Koriat, R.; Rosenberg, M. (2001). Self perception of breath odor. J. Am. Dent. Assoc., 132, 621-626. 
Forbes, B.A.; Saham, D.F.; Weissfeld, A.S. (2007). "Diagnostic Microbiology". 12 $2^{\text {th }}$ ed. Mosby company. pp. 45-65.

Goldberg, S.; Cardashl, H.; Browning, H.; Sahly, H.; Rosenbergl, M. (1997). Isolation of Enterobacteriaceae from the mouth and potential association with malodor. J. Dent. Res. 76(11), 1770-1775.

Harley, J.P.; Prescott, L.M. (1996). "Laboratory Exercises in Microbiology". $3^{\text {rd }}$ ed McGraw-Hill Company. pp. 23-56.

Holdman, L.V.; Kelley, R.W.; Morre, W.E.C. (1984). 2ed Bergey manual of systematica bacteriology. Baltimore: William and Wikins. pp. 1221-23.

Kazor, C.E.; Mitchell, P.M.; Lee, A.M. (2003). Diversity of bacterial populations on the tongue dorsa of patients with halitosis and healthy patients. J. Clin. Microbiol. 41(2), 558-63.

Oeding, M. (2005). Bad breath. J. Educ. Foundation Continuing Dent. Educ.,12, 1452-1458.

Porter, S.R.; Scully, C. (2006). Oral malodor (halitosis). BMJ, 2(333), 632-5.

Salvador, E. (2001). Classification of Halitosis. Odontologia Venezola J., 3(36), 10-14.

Settineri, S.; Mento, C.; Gugliotta, S.C.; Saitta, A. (2010). Self-reported halitosis and emotional state: impact on oral conditions and treatments. J. Italyian Dent. Assoc; 124, 345-349.

Silverman, J.; RoyEversole, L.; Edmond, L. (2002). "Essentials of Oral Medicine". BC Decker Inc. Hamilton. London. pp.144-179.

Summanen, P.H. (1999). Comparison of recovery of anaerobic bacteria using the anoxomat, anaerobic chamber, and gas pak jar systems. J. Anaerobe, 5, 5-9.

Tanaka, M.; Anguri, H.; Nonaka, A.; Shizukushi (2004). Clinical assessmented oral malodor by the electronic nose system. J. Dent. Res. 83(4), 317-321.

Wray, D.; Gordon Lowe, D.O.; Dagg, J.H. (2003). "Textbook of General and Oral Medicine". $2^{\text {nd }}$ ed. Churchill Livingstone. 213-218.

Yosef, P.; Krespi, M.D.; Mark, G.; Shrime, M.D.; Ashutosh, K. (2006). The relationship between oral malodor and volatile sulfur compound-producing bacteria. J. Head and Neck Surgery, 135, 671-676.

Young, A.; Jonski, G.; Rölla, G.; Wåler, S.M. (2001). Effects of metal salts on the oral production of volatile sulfur-containing compounds (VSC). J.Clini Periodont, 28, 776-781. 